\title{
ALCA IMPENNIS.
}

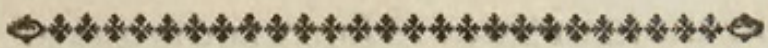

CHARACTER GENERICUS.

Roftrum edentulum, breve, compreffum, convexum, tranfverfe fæpius fulcatum.

Nares lineares.

Lingua fere longitudine roftri.

Pedes tridactyli palmati, digito poftico nullo.

Lath. ind. orn. p. 791.

CHARACTER SPECIFICUS, Ec.

ALCA roftro compreffo-ancipiti fulcato, macula ovata utrinque ante oculos.

$$
\text { Lin. Syft. Nat. p. } 210 .
$$

ALCA major.

$$
\text { Brifs. av. 6. p. 85: }
$$

Mergus Americanus.

Clus. exot. p. 103.

Qui in antareticis partibus Pinguinariis datur ordo, in arcticis idem Alcis videtur recte tribuendus. $\mathrm{Ob}$ alas breviffimas ad pinguinariarum fimilitudinem præcipue accedit fpecies quam depinximus, nec volandi capax, nec resti et firmi inceffus. Europæ et Americæ regiones maxime feptentrionales incolit, 
raro e mari in littus progediens, nifi ovum deponendi caufa, quod unicum parere dicitur in nudo aliquó loco prope marginem. Magnitudo avi eft quafi anferis communis. 


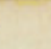




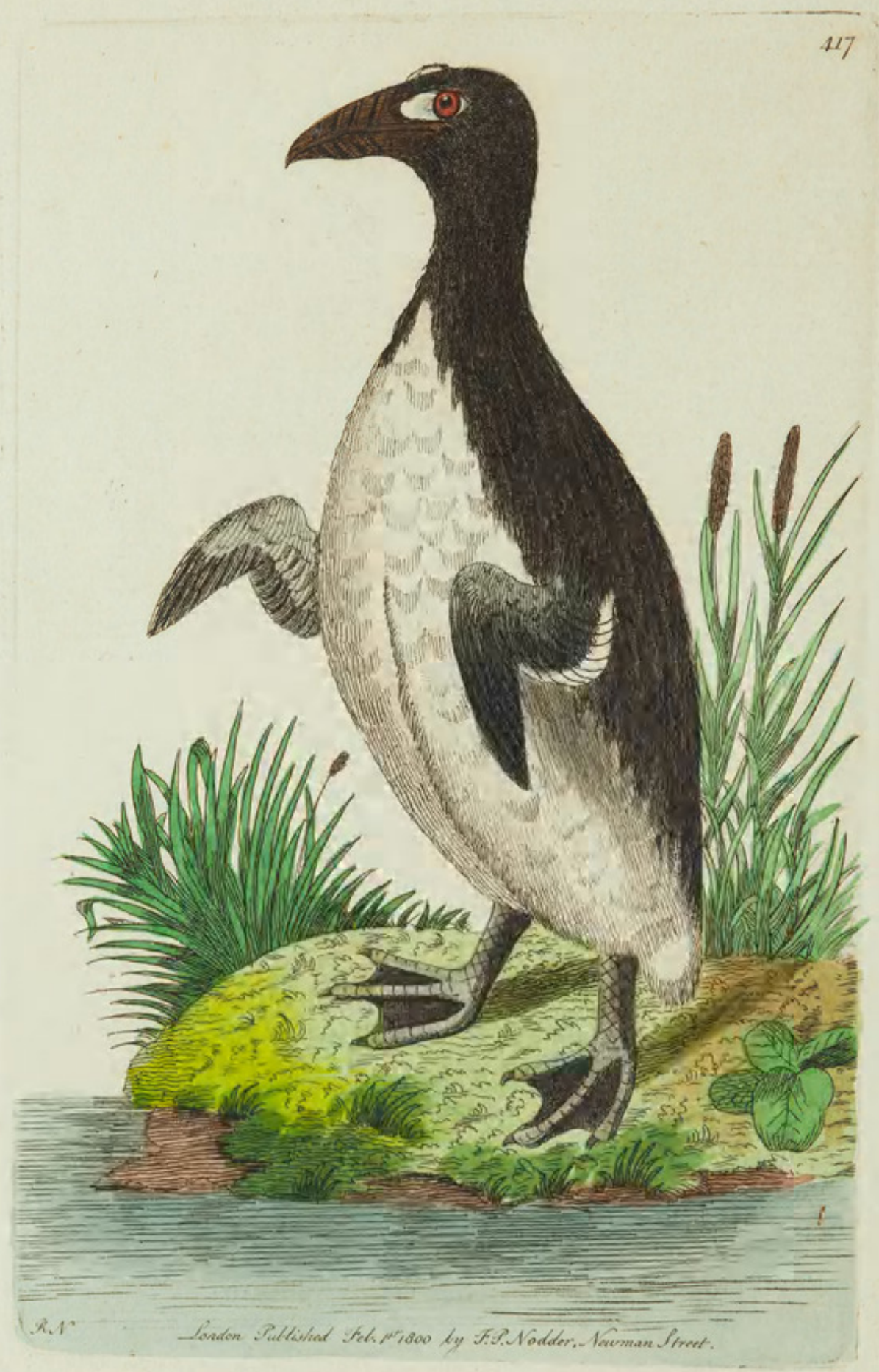


THE

\section{GREAT AWK.

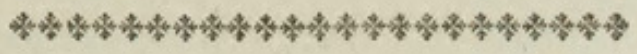 \\ GENERIC CHARACTER.}

Beak toothlefs, fhort, compreffed, convex, often tranfverlly fulcated.

Noftrils linear.

Tongue almoft the length of the bill.

Feet tridactyle, webbed, without hind toe.

SPECIFIC CHARACTER, EC.

AWK with compreffed furrowed beak, with an oval white fpot on each fide the head before the eyes.

GREAT AWK.

Northern Penguin.

$$
\text { Lath. Jyn. 3. p. } 311 \text {. }
$$

Edw. $147 \cdot$

The Alcæ or Awks feem to hold the fame rank in the northern hemifphere with the Penguins in the fouthern : the prefent fpecies, in particular, from the remarkable fmallnefs of its wings, is extremely allied to the Penguins, being equally incapacitated both for fight and for fteady walking. It is a native of the moft northern parts of Europe and Afia, and is not often feen on fhore, except in the breeding feafon, when it comes to depofit and hatch its egg, (for it is faid to lay but one,) on fome bare fpot on the edge of the coaft. It is about the fize of a goofe.

$$
\text { G } 2
$$




\section{$2 \mathrm{BHL}$ Biodiversity Heritage Library}

Shaw, George. 1800. "The Great Awk, Alca impennis [PI. 417]." The Naturalist's Miscellany 11(CXXVII), https://doi.org/10.5962/p.310864.

View This Item Online: https://www.biodiversitylibrary.org/item/276496

DOI: https://doi.org/10.5962/p.310864

Permalink: https://www.biodiversitylibrary.org/partpdf/310864

\section{Holding Institution}

Museums Victoria

\section{Sponsored by}

Atlas of Living Australia

\section{Copyright \& Reuse}

Copyright Status: Public domain. The BHL considers that this work is no longer under copyright protection.

This document was created from content at the Biodiversity Heritage Library, the world's largest open access digital library for biodiversity literature and archives. Visit BHL at https://www.biodiversitylibrary.org. 